\title{
PRODUCT SAFETY MANAGEMENT AS AN IMPORTANT AREA OF THE LEAN MANAGEMENT CONCEPT
}

\author{
doi: $\quad 10.2478 /$ czoto-2019-0072
}

Date of submission of the article to the Editor: $07 / 12 / 2018$

Date of acceptance of the article by the Editor: 13/02/2019

\author{
Nicoletta Baskiewicz ${ }^{1}$ - orcid id:0000-0002-9166-435X \\ Hacer Simay Karaalp Orhan ${ }^{2}$ - orcid id: 0000-0001-3382-9483 \\ ${ }^{1}$ Czestochowa University of Technology Poland, nicoletta.baskiewicz@wz.pcz.pl \\ ${ }^{2}$ Pamukkale University Turkey
}

\begin{abstract}
The article presents the issues of product safety management in enterprises managed in accordance with the Lean Management concept. The Lean Management concept is aimed at limiting or even completely excluding all forms of waste by intensifying and stimulating continuous improvement. One of the ways to reduce waste is to minimize waste and production shortages that arise due to failures in meeting the product safety requirements, quality criteria for a specific product. In addition, good practices in product safety in Lean organizations will be shown, which show the care for the safety of the products offered. On the basis of research, the following will be presented in the article: a general approach to product safety and detection of production deficiencies, as well as the autor's original proposal for a system ensuring the safety of manufactured products.
\end{abstract}

Keywords: safety of product, product safety management, Lean Management

\section{INTRODUCTION}

The goal of any production company is to produce products that will be in demand and popularity among customers. In order to achieve this goal, products should meet certain quality requirements both during the production process itself, after its every stage and in its subsequent operation. Requirements for ready products refer to both its basic utility (value for which the product was purchased, efficiency and safety of its use) as well as additional usefulness (additional functions that are not the basic value for which the product was acquired, external-aesthetic values). Guaranteeing this product safety during its use lies with the manufacturer and distributor of a specific product. Therefore, the producer's responsibility is to manufacture products from raw materials, materials, subassemblies or semi-finished products that guarantee the safe use of the final product. In addition to the quality of widely understood materials, the production process itself is also important, during which a specific value for the customer is created. This process must be designed, systematized and standardized to guarantee the safety of manufactured products. A product that does not meet the safety requirements should not reach the customer and should be withdrawn from the 
sale at the latest final inspection stage. Such a situation is not beneficial for the company, both in organizational and economic terms, because the product withdrawn prior to the sale indicates that the company does not operate a system to detect defects, deficiencies or defects at the production and financial stage, as defective, dangerous, non-compliant qualitative product is a place of generating costs without the possibility of obtaining financial benefits on this account. Considering the principles and guidelines according to which enterprises are managed in the Lean Management concept, a dangerous product that is not compliant with the standards, having incompatibilities and production shortages is a waste. Limiting or even completely eliminating waste is the main goal of actions taken by managers managing enterprises in accordance with the Lean Management concept.

\section{METHODOLOGY OF RESEARCH}

The purpose of this article is to present the issue of product safety management in enterprises applying the Lean Management concept. The article will include research in both literature and empirical research. In the field of literature research, it will be explained what the safety of the product is and who is responsible for it in the light of legislation. Next, the process of creating safety procedures at a given workplace will be presented. The study will also present how this process coincides with the creation of work procedures at a given position, which are mandatory in enterprises applying the Lean Management concept. The Lean Management concept is aimed at excluding all forms of waste by intensifying and stimulating continuous improvement, especially in the area of waste minimization and production deficiencies, which arise as a result of failure to meet product safety requirements resulting from quality criteria for a specific product. What is more, the health and safety legislation as well as the quality standards for the products being manufactured constitute an overriding condition determining or even shaping all procedures, including workplace ones, which create standards of behavior, including production behavior (Usugami 2018). Next, the results of the research aimed at indicating dependencies and similarities in the design of safety procedures as well as general procedures for the given position will be presented. Based on the empirical studies carried out, the author's proposal for a system ensuring the safety of manufactured products will be presented.

\section{RESULTS}

In accordance with the Act of December 12, 2003 on general product safety, the product is defined as - a new or used mobile object, as well as repaired or remanufactured for consumer use or for which it is likely to be used by consumers, even if not was intended for them, delivered or made available by the producer or distributor, both against payment and free of charge, including as part of the provision of the service; the product is not a product used as an antiquity or as a thing requiring repair or regeneration before use, as long as the supplier has notified the consumer of these properties ${ }^{1}$ A product that is safe is a product that, in normal or otherwise reasonably foreseeable conditions of its use, taking into account the time of use of the product, and depending on the type of product, manner of commissioning and installation and maintenance requirements, does not create no threat to consumers or

\footnotetext{
${ }^{1}$ Act of December 12, 2003 on general safety of products Chapter 1, art. 3, point 1.
} 
creates a negligible threat compatible with its ordinary use and taking into account the high level of requirements for the protection of health and human life. ${ }^{2}$

Thus, a dangerous product is a product that poses a serious threat, which means immediate action requiring a breach of safety requirements, taking into account immediate or out-of-date effects of the use of the product, including the likelihood of loss of health or life of consumers. The product safety assessment includes: 1) product characteristics, including its composition, packaging, assembly and commissioning instructions, and - taking into account the type of product - installation and maintenance instructions; 2) impact on other products, if it can be reasonably foreseen that it will be used together with other products; 3) the appearance of the product, its labeling, warnings and instructions for its use and handling of the used product and any other advice or information about the product provided to the consumer; 4) categories of consumers exposed to danger in relation to the use of the product, in particular children and the elderly. What is worth emphasizing that in Chapter 3 Art. 10, point 1 , the producer is obliged to market only safe products. What is more, the responsibility for the products' safety is also borne by distributors who are obliged to inform and cooperate with the supervision authority and the voivodeship inspectorate of the Trade Inspection in order to avoid or eliminate threats posed by products delivered or made available to them. The body exercising supervision over the general safety of products is the President of the Office of Competition and Consumer Protection. Supervision of the overall safety of products includes: 1) periodic monitoring and assessment of the effectiveness of controls on the compliance of products with general safety requirements, taking into account the types of controlled products and the hazards being tested; 2) developing periodic plans for product control in the scope of meeting general safety requirements and monitoring their implementation; 3) conducting proceedings regarding general product safety; 4) keeping a register of dangerous products and collecting data on products that do not meet specific security requirements; 5) gathering information regarding product safety, submitting them to competent authorities and monitoring the use of this information. It is worth noting that Henry Ford already established the Security Department in his car factory at the turn of the 19th century. In his opinion, supervising the work safety of employees and responding to accidents at work using the principles developed experimentally. It was a prototype of systemic management of occupational health and safety, which, however, did not raise the issue of product safety, as they were the subject of production standards (Pacana, 2015, Williams 1990) Violations of the safety of products leading on the one hand to the threat and on the other to the mentioned waste in accordance with the Lean Management concept can be found at every stage of the production process also in the area of noncompliant products (Thomas 2008). It is worth emphasizing here that it is possible to reduce it thanks to the use of knowledge gathered in the enterprise (Pazyuk 2005). Top management should carry out a review of the occupational health and safety management system at regular intervals in order to assess and ensure its continuing suitability and effectiveness in meeting the requirements of the standard, policy and objectives of health and safety (Sahin, Jaeger 2014; Baumgart 2014; ). Such reviews should be directed to the assessment of the functioning and effectiveness of the applied solutions, during the review the results of audits, monitoring as well as

\footnotetext{
${ }^{2}$ Act of December 12, 2003 on general safety of products Chapter 2, art. 4, point 1.
} 
corrective and preventive actions should be analyzed. Therefore, both from the point of view of the Occupational Safety Assurance System and the assumptions of the Lean Management concept, knowledge should be constantly updated, transferred and documented so that it does not expire. Written information has a different meaning for the safety of manufactured products, these documents can be divided into three main levels, it is worth noting that the Book of Work Safety and Health and Safety policy affect the shape of procedures, which in turn shape work instructions and operational documents (Karczewski, 2000):

- strategy - Work Safety and Health and Safety Policy,

- planning-procedures,

- implementation - work instructions, operational documents.

From the point of view of the discussed topic, the most important for the safety of manufactured products are instructions and operational documents. Work instructions are the third level in the hierarchy of work safety system documents and should be developed using the results of the risk analysis for a given position or activity implemented on it (Dziuba and Ingaldi, 2017). What's more, these instructions should be shaped both under the health and safety regulations and the assumptions of the Lean Management concept.

The principle of the Lean Management concept is the production of products that proceeds according to the established standards, the basic tools for setting standardized processes and procedures are standardized work documents and many other Lean tools that were used to develop workplace standards (Table 1).

Table 1

Strategy and tools for standardized processes and procedures focused on product safety in enterprises applying Lean Management

\begin{tabular}{|l|l|l|}
\hline Strategies & Basic Lean activities & Secondary Lean tools \\
\hline Creating a repeatable & Documents of standardized & Visual control tools \\
working method that & work Standardized work & Rules and procedures \\
becomes the foundation of & sheet of a production & Border samples \\
Kaizen Establishing clearly & performance sheet Work & $\begin{array}{l}\text { Process control sheets } \\
\text { defined expectations } \\
\text { Development of processes } \\
\text { ensuring the consistency of } \\
\text { all work elements }\end{array}$ \\
- The needs of the & & \\
- workforce & & \\
- Work methods & & \\
- Materials & & \\
\hline
\end{tabular}

Source: (Liker and Meier, 2011)

In standardized work processes, all positions must be filled at all times during the process, in traditional systems the absence of employees is normal, personal shortages are filled in a chaotic manner without a standard approach.

While the work standardized in Lean companies is not tantamount to applying standards in other enterprises, because in Lean companies standards are aimed at reducing waste by performing tasks with the least amount of losses, in the form of production waste or incompatible products. In practice, in enterprises for standardized 
work consists of many procedures and standards that combine into the superior method indicating the best method of work. This method determines the person responsible for the given work, machines and equipment on which the work is to be performed and the place of execution of this work. Generally, it should be stated that an effective product safety management system requires precise specification: who is responsible for what and how cooperation is implemented in the implementation of tasks and programs related to work safety. These requirements must be described so that each responsible person knows what tasks have to be done, how to implement them, what are the deadlines (Karczewski, 2000).

A good job description should contain, in addition to the description of how the work should be carried out: information on the risk, information on the necessary preventive measures, how to proceed in the event of a breakdown or disaster. The classic job safety analysis consists of the following activities, which at the same time constitute the core for the development of the work instructions (Karczewski, 2000, Kielesińska 2018):

1. Identification to determine exactly what the job or task is,

2. Setting priorities for a given task (based on frequency of execution, level of risk, number of exposed people, etc.),

3. Conducting group discussions and observation of the work process,

4. Divide the task into stages, identifying critical points for product safety (those that are not made or poorly made can exclude or limit product safety or accident),

5. Determining the rules of communication,

6. Determining the necessary preventive measures (measures to control the level of risk),

7. Working out the work instructions and attaching them to the set of factory instructions,

8. Systematic verification of instructions and if necessary - update.

Taking the above into account, it should be stated that each workstation bearing the instruction should also have an analysis of the risk of making a mistake or an accident. The risk analysis in a given position should provide information on the necessary measures to control the level of risk so that its level is acceptable, taking into account both the probability of an accident and potential losses (Niciejewska and Klimecka -Tatar, 2018). In practice, a number of measures aimed at increasing product safety, which result from compliance with health and safety regulations as well as quality standards for specific products, are among others:

- training of employees at the workplace,

- standard procedures for performing tasks at the workplace

- implementation of Lean Management tools (5s, poka yoke, SMED)

- warning and alarm devices,

- covers on machines and devices

- monitoring of threats

- signs and colors of security, visualization of the process

- measurement of harmful factors for the approval of equipment under supervision

- permission to perform specific work

- special work procedures.

During job training, all employees should familiarize themselves with the relevant work instructions, and their knowledge should be checked, for example, in the form of an 
exam or test. Therefore, systematic reminding is necessary, for example in the form of periodic position training. Instructions should be developed by the most experienced employees (Niciejewska and Klimecka-Tatar, 2017). They should be systematically verified and updated, especially when changing eg the technological process or organization of work.

\section{DISCUSSION}

Nowadays, enterprises face high requirements both in terms of caring for product safety and shaping their interaction with the environment. Companies are required to incorporate quality, ergonomics, safety and environmental protection into the company's mission and strategy. The most developing companies have quality and environmental management systems, they also take appropriate measures to implement occupational safety and health management systems, constructing the same integrated management system (Leegood 1988).

It is worth noting that the overriding function in both shaping standards and production procedures is exercised by top-down quality, health and safety at work standards. These requirements take the form of requirements defined outside the organization that significantly determine both the process standards (time, temperature, pressure, product specification) as well as standard procedures (TPM methods, Kanban rules). Both the quality requirements as well as process standards and standard procedures determine the content and nature of training, especially in the field of work instructions.

\begin{tabular}{|c|c|}
\hline $\begin{array}{c}\text { QUALITY, H \& S, ENVIRONMENT STANDARDS } \\
\text { Requirements determined outside the organization }\end{array}$ \\
\hline $\begin{array}{c}\text { STANDARD PROCEDURES } \\
\text { Requirements for the process and products } \\
\text { manufactured }\end{array}$ & $\begin{array}{c}\text { Internally defined operating methods } \\
\text { (TPM, 5S, Kanban) }\end{array}$ \\
\hline $\begin{array}{c}\text { STANDARDIZED WORK } \\
\text { General working methods during the development of which the issue of minimizing losses, } \\
\text { including the reduction of deficiencies, was taken into account }\end{array}$ \\
$\begin{array}{c}\text { OPERATOR INSTRUCTIONS } \\
\text { Detailed working methods defined in order to develop the knowledge and skills of the } \\
\text { operator, this manual is prepared and has the right to update a worker with extensive } \\
\text { experience. }\end{array}$ \\
\hline
\end{tabular}

Source: own study

Each company should, as a rule, adapt to the quality standards. These standards are developed by specific technical departments and are not subject to modification by other employees or management without the approval of the technical department. However, these requirements are presented to employees who develop methods of standardized work in order to achieve the necessary level of safety of products, operators and the environment. A work team or the management of a given area can develop requirements for shaping the quality of products offered at a given position. Examples include the risk of making a mistake in a given position or risk: injury, injury, or the operator's body being caught by the working machine (Ruddy 2013). All these potential places are marked with a safety cross on a standardized work document. Research shows that the increase of product safety is influenced by the use of information systems (Luvisi 2013, Yu 2013) 
It should be noted that the Kaizen philosophy, which is the basis for the Lean Management concept, assumes that no process is perfect and that the company has never found the perfect Lean solution. Therefore, regardless of how many times the process has been improved, each stage is filled with waste in the form of production shortages. Therefore, activities aimed at product safety in organizations applying the Lean Management concepts assume the shape and stage of the Deming PCDA cycle. (Brack, Gieskes 1990) In the case of less complicated problems, the entire process of their analysis, searching for root causes and then the right solutions can be carried out in one meeting.

\section{REFERENCES}

Brack, A., Gieskes, J.F.B., European legal developments in product liability and product safety and the Total Quality Management approach, International Journal of Materials and Product Technology 5(4), 1990, pp. 319-320.

Dziuba S.T., Ingaldi M., System Providing Food Safety and its Perception by Polish Customers- Results of Survey, 17 International Multidisciplinary Scientific GeoConference. Vol. 17 Ecology, Economics, Education and Legislation. Iss.53. Environmental Economics, STEF 92 Technology Ltd, Sofia, 2017, 845-845.

Karczewski J.T., System zarzadzania bezpieczeństwem pracy, Ośrodek Doradztwa i Doskonalenia Kadr Sp. Zo.o., Gdańsk 2000, p. 57.

Kielesińska A., Food Quality and Safety in the Brewing Industry, 12 International Conference Quality Improvement (OPI 2018), Oficyna Wydawnicza Stowarzyszenia Jakości i Produkcji, Częstochowa 2018, p. 46.

Leegood, Steve, Quality management - the impact on profit and product safety, Production Engineer London 67(2), 1988, pp. 36-37.

Liker J.K.,.Meier D.P., Droga Toyoty. Fieldbook, MT Biznes, Warszawa 2011, 158.

Luvisi, A., How information technology can support regulations and best practices for the management of health status of grapevine and product safety, Science 27(3), 2013, pp. 110-111

Niciejewska M., Klimecka -Tatar D., Difficulties in Work Safety Management in a Company Producing Steel Flat Bars, $26^{\text {th }}$ International Conference on Metallurgy and Materials, Ostrava, 2017.

Niciejewska M., Klimecka-Tatar D., Health Problems Among Employees in Small Enterprises as a Result of Improper OHS Management, 12 International Conference Quality Improvement (OPI 2018), Oficyna Wydawnicza Stowarzyszenia Jakości i Produkcji, Częstochowa 2018, p. 28.

Pacana A., Projektowanie, wdrażanie $i$ doskonalenie systemów zarządzania bezpieczeństwem i higieną pracy zgodnych z PN-N-18001, Oficyna Wydawnicza Politechniki Rzeszowskiej, Rzeszów 2015, p. 44.

Pazyuk, Yu.V., Integrated management system as a basis for increasing the competitive ability, quality and safety of building products, Promyshlennoe i Grazhdanskoe Stroitel'stvo (9), 2005, p. 31

Ruddy, M.J., Product safety: Risk management fundamentals for the safety professional, ASSE Professional Development Conference and Exposition, 2013.

Sahin, T., Jaeger, K., Tool-supported safety management in the development process through Product Lifecycle Management (PLM) | [Toolgestütztes Safety Management im Entwicklungsprozess durch Product Lifecycle Management (PLM)] 2014, Technische Sicherheit 4(4), p. 52. 
Thomas, C., Management of product quality and safety, Chilled Foods: A Comprehensive Guide: Third Edition 2008, p. 627.

Usugami J., Customer knowledge management and potential risk identyfikation: Does customet feedbackhave any impact on product and service sefety improvement of Japanese organizations? Proceedings of the European Conference on Knowledge Management, 2018, ECKM 2, 2018, p. 883.

Williams, C.E., Management of product safety assurance, GEC Review 6(1), 1990, p. 44.

Yu, Y., Li, J., Qin, X., The information key technologies for quality \& safety monitor and management of agricultural products, Advanced Materials Research 634638(1), 2013, p. 4007. 